\title{
ポリエチレンテレフタレート中のグリコール類の分析法†
}

(昭 和 36 年 5 月 4 日受理)

\section{御船 昭・石田進*}

ポリエチレンテレフタレート (PET) 中に存在するジェチレングリコール (DEG) が，重合休の性質に大きい影響を及 ぽすと考劣られるので，重合体中のエチレングリコール（EG）括よび DEG の化学的分析法を検討し，EGの分析法とし て四酢酸鉛法を DEG の分析法として過ヨウ栔酸・重クロム酸カリウム法を見出し，これによって EG-DEG 混合物では DEG 含有量を相対䛊差 $1 \%$ 以下で求められるようになり，重合体中の DEG も実用に差支えない程度に定量できるよ5 になった。これによって求めた $T_{\mathrm{s}}=258.1^{\circ} \mathrm{C}$ の重合体の $\mathrm{DEG}$ 含量は約 $2 \mathrm{~mol} \%$ である。

\section{1 緒言}

ポリエチレンテレフタレート (PET) は, テレフタル酸ジメチ ル (DMT) とエチレングリコール (EG) とのエステル 交換反応 によりビスヒドロキシェチルテレフタレートを合成し，更に脱エ チレングリコール缩合によって得られる重合体であるが，これら の反応中に EGの 2 分子縮合によって DEG を生じ, これが重合 体鎖中に入ってくることにより, 重合体の軟化点を下げ，種々の 性質に影響をおよぼすようになる。その存在量を確かめるには, 上述の軟化点で相対的なものを知ることもでさるが，化学的な方 法によって確認することも必要である。この場合どのような分析 法をとるにしても PET を加水分解することが必要であり, 得ら れた EG-DEG-水混合液について EG ないしは DEG の分析が 必要となってくる。この見地から以下の実験を行なった。

\section{EG の 分 析}

EG の分析には一般に 1,2-グリコール特有の反応を利用するの が常道であり，それには Malaprade の反応として知られている 過ヨウ素酸またはその塩による酸化反応, Criegee の反応と呼ば れる四酢酸鉛による酸化反応等があるが，分析法としては，もっ ぱら前者が用いられている1。この反応の最大の利点は水溶液中 で行ないうる点であって, 分析法として採用されているのもこの 理由による。

$$
\mathrm{HO} \cdot \mathrm{CH}_{2} \cdot \mathrm{CH}_{2} \cdot \mathrm{OH}+\mathrm{HIO}_{4} \longrightarrow 2 \mathrm{CH}_{2} \mathrm{O}+\mathrm{HIO}_{3}+\mathrm{H}_{2} \mathrm{O}
$$

さて $\mathrm{EG}$ の存在量は $\mathrm{HIO}_{4}$ の消費量, あるいは生成ホルムアルデ ヒド量から求められる。前者のもっとも簡単な求め方はブランク および試料について反応させたのちヨウ化カリウムで $\mathrm{HIO}_{4}, \mathrm{HIO}_{3}$ を還元し, 生じたヨードを滴定し $\mathrm{HIO}_{4}$ と $\mathrm{HIO}_{3}$ の当量の差から 計算する方法であるが，この方法は両者の当量の差が小さく誤差 が大きくなる2)。これを避けるために種々の試み2,3)がなされてい るがいずれもかえって誤差の原因をふやすことになり改善されて いない。ホルムアルデヒド量の測定についても同様である4。さ らにこの方法は過㮃の $\mathrm{IO}_{4}$ - が生成したホルムアルデヒドを酸化

† 本報を「ポリエチレンテレフタレートに関する研究（第 2 報)」とする．第 1 報，工化 65，405 (1962).

* 帝国人造絹系株式会社岩国第 2 研究所:山口県岩国市今津.

1) G. O. Curme, Jr. "Glycols" p. 337 (1952) Reinhold Publish Co., New York.

2) S.D. Nogare, A. N. Oemler, Anal. Chem. 24, 902 (1952).

3) E. I. Fulner et al., Ind. Eng. Chem. Anal. Ed. 12, 729 (1940).

4) G. Hoepe, W. D. Treadwell, Helv. Chim. Acta. 25, 353 (1942).
するため EG 濃度として過大な結果を与える難点がある。これは 後述の実験でも立証された。そこで著者らは従来少なくとも水溶 液系では分析法として取上げられていない四酢酸鉛法を検討し た。すなわち次式で示される反応を利用する。

$\mathrm{HO} \cdot \mathrm{CH}_{2} \cdot \mathrm{CH}_{2} \cdot \mathrm{OH}+\mathrm{Pb}\left(\mathrm{OOC} \cdot \mathrm{CH}_{3}\right)_{4}$

$\longrightarrow 2 \mathrm{CH}_{2} \mathrm{O}+\mathrm{Pb}\left(\mathrm{OOC} \cdot \mathrm{CH}_{3}\right)_{2}+2 \mathrm{CH}_{3} \mathrm{COOH}$

この反応は一般に, 氷酢酸, ベンゼン等の非水溶媒中で行なわ れる。それは四酢酸鉛が水の存在下で加水分解を起して $\mathrm{PbO}_{2}$ に なるからである。反応は氷酢中では非常に反応速度が遅く, 反応 の完結に一昼夜を要することもあることが知られている5)。一方 Baer らは 1,2-グリコールの水溶液に四酢酸鉛（以下LTAと記 す）の酢酸溶液を加えると酸化反応の速度は大となり $\mathrm{PbO}_{2}$ の生 成にもかかわらず EG の分解がほとんど 100\% 進行することを 認めている6)。著者らはこの知見に基づき分析法としての検討を 行なった。

\section{$2 \cdot 1$ 予 備 実 験}

分析法としてこの方法が使用できるかどうかを見出すためにつ ぎの 4 種のテストを行なった。試薬の LTA は Dimroth の方法7) により $\mathrm{Pb}_{3} \mathrm{O}_{4}$ より合成し水酢中に密栓して貯蔵したものを用い た。

（1）水に LTA 水酢溶液を加えると瞬間的に加水分解が起り $\mathrm{PbO}_{2}$ の赤茶色沈殿によって系はココア状となる。

（2）この䀣濁 $\mathrm{PbO}_{2}$ はョウ化カリウムによって還元されて, 定量的に $\mathrm{I}_{2}$ を遊離する。

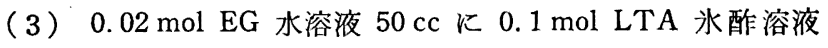
$20 \mathrm{cc}$ を添加，5分放置後 $10 \%$ ヨウ化カリウム水溶液 $50 \mathrm{cc}$ 加え 15 分放置する。その後 $0.2 \mathrm{~N}$ チオ硫酸ナトリウムで滴定す ると常温放置の場合約 $60 \%, 60^{\circ} \mathrm{C}$ 放置で約 $90 \%$ の EG が酸化 されていることがわかった。

（4）EG 水溶液中では LTA の加水分解速度がかなり遅くな る。またこれに酢酸りーダを添加したところ加水分解がほとんど 起らないことを見出した。この時はまた EG の酸化がほとんど完 全に進行することが予想される。

\section{$2 \cdot 2$ 四眽酸鉛法による EG の定量}

前述の知見に基ついて，以下の四酢酸鉛法を実施し精度の高い 分析法を確立することがでさた。

（1）試薬：LTA の前述の合成品を承酢中に 保存したものを 用いた。皮瞷市肘 1 級品に $3 \%$ の無酢を加光還流 1 時間後精留 し bp $108^{\circ} \mathrm{C}$ のものをとり，これに少量の $\mathrm{KMnO}_{4}$ を加兄て再精

5）船久保, “有機化合物確認法” (上) p. 58 (1954) 盖賢堂.

6) E. Baer et al., J. Am. Chem. Soc. 61, 2607 (1939).

7) O. Dimroth, R. Schweizer, Ber., 56, 1375 (1923). 
留して使用した。醀酸ナトリウム, 重炭酸ナトリウム, ヨウ化》 リウムは市販 1 級品をそのまま用い, チオ硫酸ナトリウムは 0.05 $\mathrm{N}$ の濃度にして使用した。

（2）操作: EG 水溶液は濃度が約 $0.02 \mathrm{~mol}$ になるよ5にう すめ, 試料溶液 $10 \mathrm{cc}$ を共栓付三角フラスコにとり酢酸ナトリウ ム $20 \mathrm{~g}$ を加光, 時々振って約 10 分間放置する。これに LTA

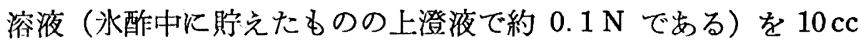
加えマグネチックスターラーにより 30 分かきまぜ, さらに重崖 酸ナトリウム $1 \mathrm{~g}$ 扣よびヨウ化カリウム $5 \mathrm{~g}$ を加えて 20 分放 置後純水 $50 \mathrm{cc}$ を添加, $0.05 \mathrm{~N}$ のチオ硫酸ナトリウムで滴定す る。試料のかわりに水を用いてブランクテストを行ない，それぞ れのチ才硫酸ナトリウム所要量を $A, B \mathrm{cc}$ とすると $\mathrm{EG}$ 濃度は 次式で与えられる。

$$
\mathrm{M}(\mathrm{EG} \text { モル濃度 })=(B-A) \cdot \mathrm{N} \cdot f / 2 \mathrm{~V}
$$

ここで $\mathrm{N}, f$ はチ才硫酸ナトリウムの規定度括よびファクター， $V$ は試料溶液採取量 (cc) を示す。

（3）実験結果：上述の方法で $0.02 \mathrm{~mol}$ および $0.04 \mathrm{~mol}$ の EG 水溶液を用いて分析の精度を調べた結果は表 1 に示すと拉り である。表から明らかなよ5に，測定の精度は極めてよく $0.5 \%$ 以内で正しい值が得られて括り, 分析法として十分使用しうるす のである。

\begin{tabular}{|c|c|c|c|c|c|}
\hline $\begin{array}{c}\text { 滴定值 } A \\
\text { (cc) }\end{array}$ & $\begin{array}{c}\text { 滴定値 } B \\
\text { (cc) }\end{array}$ & 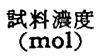 & $\begin{array}{l}\text { 武料溶液 } \\
\text { (cc) }\end{array}$ & $\begin{array}{c}\text { 測定湝庋 } \\
(\mathrm{mol})\end{array}$ & 獸 \\
\hline 10.05 & 17.95 & 0.0200 & 10.0 & 0.0199 & -0.5 \\
\hline 10.06 & 17.96 & 0.0200 & 10.0 & 0.0199 & -0.5 \\
\hline 5.37 & 13.48 & 0.0403 & 20.0 & 0.0404 & +0.3 \\
\hline 5. 28 & 13. 37 & 0.0403 & 20.0 & 0.0403 & \pm 0 \\
\hline
\end{tabular}

\section{$2 \cdot 3$ 過ヨウ素酸ソーダ法による EG の定量}

前項の LTA 法との比較のために過ヨウ素酸ナトリウム法で分

裴 $2 \mathrm{NaIO}_{4}$ による $\mathrm{EG}$ の分析

\begin{tabular}{ccc}
$\begin{array}{c}\text { 試料濃度 } \\
(\mathrm{mol})\end{array}$ & $\begin{array}{c}\text { 湘定灌度 } \\
(\mathrm{mol})\end{array}$ & $\begin{array}{c}\text { 詔 } \\
(\%)\end{array}$ \\
\hline 0.0203 & 0.0212 & +4.3 \\
0.0215 & 0.0226 & +5.0 \\
0.0422 & 0.0442 & +4.8 \\
0.0405 & 0.0430 & +6.1
\end{tabular}

厶 $4.2783 \mathrm{~g}$ を純水 $1 l$ に溶解して作り、浀硫酸お素酸ナトリヴウ リウムは市肘 1 級品, $\mathrm{Na}_{2} \mathrm{~S}_{2} \mathrm{O}_{3}$ は特級品を用いた。

（2）操作：300 cc 共栓三角フラスコに $0.02 \mathrm{~mol}$ 過ヨウ素酸 ナトリウム水溶液 $20 \mathrm{cc}$ および純水 $50 \mathrm{cc}$ をとる。よく振って混 合後 $\mathrm{EG}$ 水溶液（約 $0.02 \mathrm{~mol} \mathrm{Kなるよ5にうすめたもの）} 10 \mathrm{cc}$ を追加, 再び振って 30 分密栓放置する。これに KI $2 \mathrm{~g}$ 濃硫酸 $2 \mathrm{cc}$ を加える。 5 分後に $0.1 \mathrm{~N}^{\prime}$ の $\mathrm{Na}_{2} \mathrm{~S}_{2} \mathrm{O}_{3}$ で遊離した $\mathrm{I}_{2}$ を滴 定し，常法により EG 濃度を計算する。

\section{$2 \cdot 4$}

以上の結果から LTA 法は氷酢の精製, 試楽の防湿等のわずら わしさがあるが，精度の点で遙かにすぐれて拈り，DEG の量を 酸化によって求めた全グリコール量から EG 濃度を差引いて求め ようとするならば LTA 法を使用するのが妥当で女ることが見出 された。しかし大さっぱな EGの測定を行ならには従来の過ヨウ 素酸ナトリウム法でも差支えはない。

\section{DEG の 分 析}

重合体中に存在与万 DEG の量け比較的少量であって, 従来こ
の定量は十分な精段を出すに系らなかった。重合体をアルカリに よって加水分解しこの中に存在するテレフタル酸を EG-DEG-水 系と分離するのは処理条件の選択によって可能であるから, EGDEG-水系の中の DEG を定量することが問題となる。DEG は EG に対して非常に少なく $5 \mathrm{wt} \%$ 以下と考えられるし, その水 溶液濃度は $\mathrm{EG}$ モル濃度で 0.1〜0.01の程度と考学られる。また EG と異なり LTA とか過ヨウ素酸のような特有な酸化剤がない ことも問題の解釈を困難にした。さて DEG の分離定量には 2 通 りの方法が考えられ, EG+DEG の濃度を求めEGを差引く方法, $\mathrm{EG}$ と DEG の濃度を別々に求める方法の二つである。前者の方 法として EG+DEG を求めるには, 重クロム酸カリ酸化と過マン ガン酸カリウム酸化があり，後者で DEG を求めるには (A) フ エロシアン化カリウム法8) (B) 燐モリブデン酸カリウム法9)等の ポリエチレンオキシド型非イオン活性昘定量法が考えられた。著 者らはまずフェロシアン化カリウム法打よび燐モリブデン酸ナト リウム法を検討したが所期のコンプレックスが得られず, これ以 上検討せず，前者の方法を試みることにした。この場合 $\mathrm{DEG}$ が 多ければ過ヨウ素酸法で EGを求め, 重クロム酸カリウム法で全 グリコールを求めることによりある程度満足すべき結果が得ら れるが, DEG の含有率が低い時には両法とも $1 \%$ 以上の誤差を もっているので分析の意味がなくなることが判った。そこで再

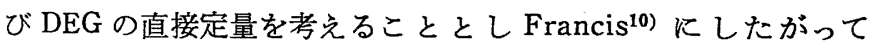
EG を過ヨウ素酸分解して生じたホルムアルデヒドを蒸留によっ て追出し，系中に残った $\mathrm{DEG}$ を $\mathrm{K}_{2} \mathrm{Cr}_{2} \mathrm{O}_{7}$ 酸化によって定量し たところ, 種々難点はあったが微量の DEG を直接定量すること が可能となった。この際問題となったのはつぎの点であるが，こ れはそれぞれ適当な解決法を見出した。

（1）アルデヒド蒸留の場合, 過剰の過ヨウ素酸が DEG を酸 化するので, これを防ぐためあらかじめ EG 量を求めて過剩量を 一定にし，かつ一定つ蒸留法を忠実に守ることにして解決した。

（2）過剩》過ヨウ素酸はまた過ヨウ素酸自体の酸化還元電圧 が非常に高く, $\mathrm{K}_{2} \mathrm{Cr}_{2} \mathrm{O}_{7}$ 酸化時に DEG を酸化する可能性が強 い。そのため $\mathrm{H}_{2} \mathrm{O}_{2}$ でこれをヨウ素酸にしておかねばならぬが, $\mathrm{H}_{2} \mathrm{O}_{2}$ はホルムアルデヒドをギ酸に酸化するので, ホルムアルデ ヒドがなくなった後に添加しなければならない。

(3) 酸化後の $\mathrm{K}_{2} \mathrm{Cr}_{2} \mathrm{O}_{7}$ の余分はヨウ素酸が残っているため 滴定では求められぬが, 著者らはこれを比色法によって解决した。

（4）試料に無機塩類があると沸点を上㫒し，ホルムアルデヒ ド追出しの時 DEG 酸化の危険があるので, 重合体加水分解に $\mathrm{Ba}(\mathrm{OH})_{2}$ を用い, テレフタル酸バリウムとして不溶性にして取 除くことにした。

\section{1 実 験 方 法}

原理は次式で示される。

$$
\mathrm{HO} \cdot \mathrm{CH}_{2} \cdot \mathrm{CH}_{2} \cdot \mathrm{OH}+\mathrm{HIO}_{4} \longrightarrow 2 \mathrm{CH}_{2} \mathrm{O}+\mathrm{HIO}_{3}+\mathrm{H}_{2} \mathrm{O}
$$

生じたホルムアルデヒドを追出して余分の $\mathrm{HIO}_{4}$ を $\mathrm{H}_{2} \mathrm{O}_{2}$ で分解

$$
\mathrm{HIO}_{4}+\mathrm{H}_{2} \mathrm{O}_{2} \longrightarrow \mathrm{HIO}_{3}+\mathrm{H}_{2} \mathrm{O}+\mathrm{O}_{2}
$$

系中に残った DEG を硫酸酸性で $\mathrm{K}_{2} \mathrm{Cr}_{2} \mathrm{O}_{7}$ で酸化する。

$$
3 \mathrm{HO} \cdot \mathrm{CH}_{2} \cdot \mathrm{CH}_{2} \cdot \mathrm{O} \cdot \mathrm{CH}_{2} \cdot \mathrm{CH}_{2} \cdot \mathrm{OH}+10 \cdot \mathrm{K}_{2} \mathrm{Cr}_{2} \mathrm{O}_{7}+40 \cdot \mathrm{H}_{2} \mathrm{SO}_{4}
$$$$
\longrightarrow 10 \cdot \mathrm{K}_{2} \mathrm{SO}_{4}+10 \cdot \mathrm{Cr}_{2}\left(\mathrm{SO}_{4}\right)_{3}+12 \cdot \mathrm{CO}_{2}+55 \cdot \mathrm{H}_{2} \mathrm{O} \quad \text { (III) }
$$

余分の $\mathrm{K}_{2} \mathrm{Cr}_{2} \mathrm{O}_{7}$ を $448 \mathrm{~m} \mu$ フィルターを用いて光電比色計で定

8）第一工業製浆礼報 昭 30-6 月 p. 138 .

9) 籁一工業製薬社報 昭 30-7 月 p. 160 .

10) C. V. Francis, Anal. Chem. 21, 1238 (1949), 
量する。

（1）試菜：過ヨウ素酸は橋本化学製のものをそのまま使用, $3 \%$ 過酸化水素水は 1 級市肘品（30\%）を10 倍に5すめて使用。 シッフの試薬はフクシン $1 \mathrm{~g}$ を純水 $1 l$ 亿溶解口過し, $30 \% \mathrm{NaH}$ $\mathrm{SO}_{3}$ 水溶夜 $20 \mathrm{cc}$ を加えほとんど完全に色が消えたところで濃 塩酸 $10 \mathrm{cc}$ を加えて作った。 $\mathrm{K}_{2} \mathrm{Cr}_{2} \mathrm{O}_{7}$ は特級品をそのまま使用し た。

（2）操作：試料の $E G$ 濃度をあらかじめ過ヨウ素酸法で求 め, EG が 3〜4 mmol になるよう試料採取量を決める。キェル ダールフラスコに純水 $50 \mathrm{cc}$ をとり過ヨウ素酸を EG に対し $10 \%$ 余計になるように科って入れさらに陚料を加兄，純水で全量が $200 \mathrm{cc}$ Kなるよ5うすめる。この液をバーナーで加熱しアルデヒ ドを水とともに留出させるが, フラスコ内の液が $30 \mathrm{cc}$ 以下にな らぬよらにする。もし留出液にまだ - CHO が検出され, 内部の 液が $30 \mathrm{cc}$ 以下になる時には水を $100 \mathrm{cc}$ 追加して操作を続ける。 （通常 2 回位追加する）フラスコ内残液は $\mathrm{Na}_{2} \mathrm{CO}_{3}$ で中和，3\% $\mathrm{H}_{2} \mathrm{O}_{2}$ 水 $5 \mathrm{cc}$ を加えて振り，水で $150 \mathrm{cc}$ に与すめ再蒸留する。 液量が $30 \mathrm{cc}$ になったらやめて放冷 $50 \mathrm{cc}$ のメスシリンダーに

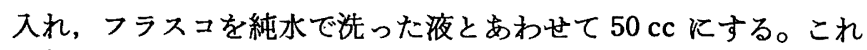
を丸底フラスコに移し $1: 1$ 硫酸 $100 \mathrm{cc}$ を加え遊離したヨウ素 の色がなくなるまで逆流冷却器をつけて沸騰させ冷却する。これ に $0.1 \mathrm{~N}-\mathrm{K}_{2} \mathrm{Cr}_{2} \mathrm{O}_{7} 20 \mathrm{cc}$ を加光, 再び加熱沸騰させ 45 分後酸化 完了とし常温まで冷却 $500 \mathrm{cc}$ メスフラスコに入れ 純水で標線ま でろすめて比色サンプルとする。純水 $50 \mathrm{cc}$ について $1: 1$ 硫酸 を加克る操作から同じ操作を行なってブランクとする。この二つ のサンプルを光電比色計島津 $\mathrm{DF}-\mathrm{N}$ 型付属の $2 \mathrm{~cm}$ セルに入れ サンプルを溶媒側, ブランクを溶液側のパスに入れ $448 \mathrm{~m} \mu$ フ イルターで吸光度を求め, 準備した検量線により DEG 含量を決 定できる。検量線は $0.2 \mathrm{~mol} \mathrm{EG}$ 水溶夜 $20.00 \mathrm{cc}$ K $0.006 \mathrm{~mol}$

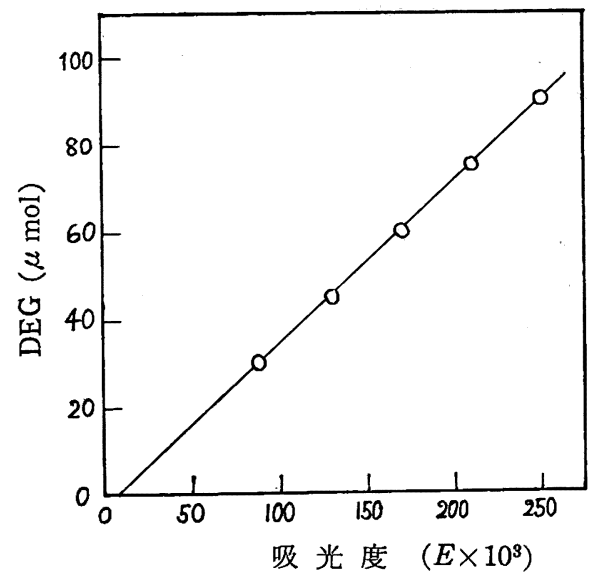

四 1 DEG 検 量 線
表 3 DEG 検量線 の作製

\begin{tabular}{|c|c|c|c|c|c|}
\hline $\begin{array}{l}\text { DEG 溶液 } \\
\text { 混合量(cc) }\end{array}$ & $\begin{array}{c}\mathrm{DEG} \text { 泳度 } \\
(\mu \mathrm{mol})\end{array}$ & 吸光度 & $\begin{array}{l}\text { DEG 溶波 } \\
\text { 混合量 }(\mathbf{c c})\end{array}$ & $\begin{array}{c}\mathrm{DEG} \text { 溧度 } \\
(\mu \mathrm{mol})\end{array}$ & 吸光度 \\
\hline 5.00 & 30 & 0.088 & 10.00 & 60 & 0.170 \\
\hline 5.00 & 30 & 0.087 & 12.50 & 75 & 0.208 \\
\hline 7.50 & 45 & 0.128 & 15.00 & 90 & 0.250 \\
\hline 10.00 & 60 & 0.170 & & & \\
\hline
\end{tabular}

DEG 水溶液を表 3 亿示す量混合して操作を加兄測定し作製した (図 1 )。

\section{$3 \cdot 2$ 実験結果}

まず DEG $30,60,90 \mu \mathrm{mol}$ 含む.ような $\mathrm{DEG}$ 水溶液を作り， 前項に述べた操作にしたがって分
表 $4 \mathrm{DEG}$ 水溶液での確認 \begin{tabular}{cc} 
漹料 DEG $(\mu \mathrm{mol})$ & 吸光度 \\
\hline 30.0 & 0.086
\end{tabular}

$60.0 \quad 0.170$

$90.0 \quad 0.253$

析したところ（EG がないから過ヨウ素酸工程を行なわず）表 4 の如き結果となり，前記の検量線が十分分析に用いらることを確 めてから，ポリマー中の DEG の分析を行なった。ポリマー中の DEG を定量するにはまず加水分解を行な5必要があり，陚料 $2 \mathrm{~g}$ をa $(\mathrm{OH})_{2} 10 \mathrm{~g}$ 純水 $10 \mathrm{~g}$ と封管に入れ沸水中で加水分解 5 時間後取出してグラスフィルターでロ過, 硫酸で $\mathrm{BaSO}_{4}$ 打よ びテレフタル酸またはその Ba 塩を沈殿させ再び $\mathrm{Ba}(\mathrm{OH})_{2}$ で中 和, 遠心沈殿器で沈殿を分離して $500 \mathrm{cc}$ にうすめサンプルとし 前項の分析に供した。軟化点 $258.1^{\circ} \mathrm{C}$ の゚゚マーについて分析の 結果, 表 5 に示す如く一応相対のばらつき $\pm 10 \%$ 前後で DEG 含有量が決定できた。DEG-EG の混合液では $\pm 1 \%$ 位であった から，このばらつきの增加は加水分解操作に基づくものと考兄ら れる。

表 5 PET '中の DEG の分析

\begin{tabular}{cccc} 
陚料番号 & $\begin{array}{c}\text { DEG \% } \\
\text { (測定侹) }\end{array}$ & $\begin{array}{c}\text { ブランク } \\
(\%)\end{array}$ & $\begin{array}{c}\text { DEG } \\
(\%)\end{array}$ \\
\hline $1-1$ & 2.60 & 0.62 & 2.0 \\
$1-2$ & 2.56 & 0.62 & 2.0 \\
$2-1$ & 2.32 & 0.50 & 1.8 \\
$3-1$ & 2.66 & 0.61 & 2.1
\end{tabular}

4 総括

以上の結果からポリエチレンフタレート中の副生 DEG の化学 的定量が相対のばらつき $\pm 10 \%$ 前後で可能となり，奏用上差支 えない分析ができるようになった。同時に DEG-EG 混合物で相 対のばらつき $1 \%$ で DEG 含量が決定できるよ5になり，また EG 単独では四酢酸鉛を用いる高精度の分析法を確立することが できた。この方法を用いて求めた軟化点 $258.1^{\circ} \mathrm{C}$ の重合体の $\mathrm{DEG}$ 含量は約 $2 \mathrm{~mol} \%$ であって他の方法から推定される值に大体一 致している。

終りに臨み，発表を許可された会社当局および討論と実験に協 力いただいた研究室の諸氏に感謝致します。 